\title{
PENGARUH INDIKATOR KRISIS KEUANGAN GLOBAL TERHADAP INDEKS HARGA SAHAM GABUNGAN (IHSG) DI BURSA EFEK INDONESIA
}

\author{
Tiara Kania Dewi \\ Sri Adji Prabawa \\ Program Studi Manajemen \\ Fakultas Ekonomi dan Bisnis Universitas Bengkulu
}

\begin{abstract}
ABSTRAK
Tiara Kania Dewi, Sri Adji Prabawa; Penelitian ini menganalisis pengaruh indikator krisis keuangan ke Jakarta Composite Index (JCI) di Bursa Efek Indonesia. Penelitian ini dilakukan dengan mengumpulkan data sekunder. Data dari Bank Indonesia, Bursa Efek Indonesia dan lembaga lain yang diterbitkan IHSG. Data dianalisis dengan menggunakan statistik. Regresi berganda model analisis regresi yang digunakan dalam menganalisis data. Uji $\mathrm{F}$, uji $\mathrm{t}$ dan uji determinasi ditemukan dari sampel penelitian ini. Data sampel adalah 18 bulan. Hasilnya menemukan semua indikator krisis keuangan yaitu nilai tukar US \$, tingkat SBI, volume perdagangan, dan inflasi, pengaruh IHSG. Pengaruh empat variabel yang $56,6 \%$. Pengaruh krisis keuangan indikator IHSG ditunjukkan oleh Adjusted R2 = 0,566 atau 56,6\%, dan 43,4\% lainnya dipengaruhi oleh variabel lain. Hasil penelitian menunjukkan bahwa proposisi IHSG dipengaruhi oleh nilai tukar US \$, tingkat SBI, kecuali volume perdagangan, dan inflasi.
\end{abstract}

\section{ABSTRACT}

Tiara Kania Dewi, Sri Adji Prabawa; This research analysis the influence of financial crisis indicators to Jakarta Composite Index (JCI) at the Indonesia Stock Exchange. The research was done by collecting the secondary data. The data from Bank Indonesia, Indonesia Stock Exchange and other institution which published IHSG. The data was analysed using the statistic. The regression of multiple regression analysis model was used in analysing data. $F$ test, $t$ test and determination test was found from the sampel of this research. The sample data were 18 months. The result found all indicators of financial crisis namely exchange rate US\$, rate of SBI, volume trading, and inflation, influence IHSG. Influence of four variables are 56.6\%. The influence of indicator crisis finance of IHSG is shown by Adjusted $R 2=0.566$ or $56.6 \%$, and $43.4 \%$ other is influenced by the other variable. The result show that the proposition of IHSG are influenced by exchange rate US\$, rate of SBI, except volume trading, and inflation

Key words: Exchange rate US\$, rate of SBI, volume trading, inflation, IHSG

\section{PENDAHULUAN}

Ekonomi dianggap sebagai salah satu faktor yang paling penting di dunia, karena itu, jika krisis melanda perekonomian dunia, dunia akan menderita. Mulai dari isu-isu perdagangan dan masalah uang yang dapat mempengaruhi populasi global, segala masalah berat mengenai ekonomi harus segera diberantaskan sebelum situasi tersebut memperburuk keadaan dunia. Salah satu dari masalah berat tersebut adalah krisis ekonomi. Krisis ekonomi merupakan suatu situasi di mana perekonomian suatu negara mengalami penurunan tiba-tiba yang disebabkan oleh krisis keuangan. Krisis ekonomi dapat disebabkan oleh banyak hal. Dari dampak politik, berbagai aspek yang berhubungan dengan keuangan dan ekonomi itu sendiri, timbulnya krisis ekonomi dapat membuahkan dampak yang korup bagi dunia. Beberapa dampak yang dinyatakan adalah kemiskinan, runtuhnya sistem ekonomi maupun politik di satu negara atau lebih, dan berbagai hal yang berhubungan dengan perekonomian dan keuangan. ( Satria,2011) 
Dengan keadaan ekonomi global yang memburuk sejak tahun 2008 di Amerika, krisis tersebut telah menjalar ke beberapa negara di dunia. Walaupun Amerika sekarang sedang mengalami resesi, krisis ekonomi lebih besar membara di negara Eropa bernama Yunani. Meskipun isu ini baru di kenal dunia pada tahun 2009, isu tersebut telah timbul pada tahun 2001 ketika Yunani bergabung dengan mata uang Eropa, yaitu euro. Bahkan ketika mata uang Yunani yaitu drachma bergabung dengan euro, Yunani mengakui bahwa mereka belum mencapai persyaratan yang dibutuhkan untuk memasuki zona euro. Dari saat itupun kita dapat melihat bahwa ekonomi Yunani dapat jatuh karena ketidakstabilannya. Meski pada pertengahan tahun 2000an Yunani mengalami ekonomi yang stabil dan kenaikan GDP, krisis ekonomi Yunani berlanjut ketika seorang bernama George Papandreou menjadi perdana menteri Yunani. Walaupun niatnya baik dan ambisius, tindakan perdana menteri Yunani ditambah dengan pemerintahan Yunani terbukti gagal karena ekonomi Yunani semakin memburuk. Tindakan pemerintahan Yunani termasuk memotong defisit negara pada tahun 2010 sampai 2011, pengumuman penghematan paket yang lebih luas termasuk membekukan gaji sektor publik dan pajak yang lebih tinggi bagi rumah tangga berpenghasilan rendah dan menengah. ( Satria, 2011)

Krisis Yunani berawal dari akumulasi defisit anggaran yang setiap tahunnya rata-rata mencapai sebesar 6\% dari PDB selama 30 tahun. Yunani nampaknya tidak menerapkan prinsip kehati-hatian (prudent) dalam kebijakan defisitnya, sehingga defisit anggaran mencapai dua kali lipat dari ketentuan Uni Eropa (UE) yang maksimum ditetapkan sebesar 3\%. Sementara itu pasar obligasi di dalam negerinya juga masih sangat terbatas, untuk itu Yunani menjual surat utang Negara (SUN)-nya kepada investor di Prancis, Swiss, dan Jerman. Sebagai dampak akumulasi defisit, saat ini defisit Yunani mencapai 13,6\% dari PDB. (http//www.bi.go.id)

Semenjak itu ekonomi Yunani menjadi sangat rapuh dan lemah sehingga Yunani terus menerus bertindak dengan meminjam dan berhutang dari negara lain serta meminta banyak bantuan dari negara-negara maju. Hutang yang mencapai 340 milyar euro sampai saat ini. Karena tindakan tersebut tanpa waktu yang lama, krisis ekonomi Yunani menyebar dan menjalar ke negara-negara lain di dunia.

Krisis yang sedang melanda eropa tentu memberikan dampak terhadap Indonesia. Sebagai Negara yang ikut andil dalam perekonomian dunia. Indonesia merupakan negara paling tahan terhadap dampak krisis Eropa dan Amerika Serikat dibandingkan negara Asia lain karena tidak terlalu mengandalkan ekspor sebagai tumpuan perekonomian. Saat ini, krisis keuangan di Eropa dan Amerika Serikat berdampak secara tidak langsung terhadap negara-negara di Asia. Negara-negara Asia hanya terkena dampak turunan yang disebabkan perlambatan ekonomi negara tujuan ekspor.

IHSG bergerak naik turun dengan tajam, merespons perkembangan dari penanganan krisis Eropa. Data positif soal deflasi Indonesia ternyata tak cukup untuk memberikan sentimen positif. Mengawali perdagangan, IHSG langsung melemah dan pelemahan semakin tajam pada hari berikutnya. Sentimen utamanya adalah anjloknya bursa global merespons rencana referendum Perdana Menteri Yunani George Papandreou. Namun seiring besarnya kemungkinan kandasnya rencana referendum, bursa global membaik, diikuti pula oleh bursa Indonesia. Berikut pergerakan IHSG pada bulan oktober 2011 lalu:

1. Senin (31/10/2011), IHSG terpangkas 39,113 poin $(1,03 \%)$ ke level $3.790,847$.

2. Selasa $(1 / 11 / 2011)$, IHSG anjlok 105,835 poin $(2,79 \%)$ ke level $3.685,012$.

3. Rabu (2/11/2011), IHSG ditutup melesat 78,022 poin $(2,11 \%)$ ke level 3.763,034.

4. Kamis (3/11/2011), IHSG terpangkas 57,224 poin $(1,53 \%)$ ke level 3.705,810.

5. Jumat (4/11/2011), IHSG menguat 77,818 poin $(2,10 \%)$ ke level 3.783,628.

Sementara bursa Wall Street mengalami koreksi, investor merasa 'putus asa' terkait masalah penyelesaian krisis utang Yunani. Pada perdagangan Jumat (4/11/2011), indeks Dow Jones industrial average ditutup melemah 61,23 poin $(0,51 \%)$ ke level $11.983,24$. Indeks Standard \& Poor's 500 juga melemah 7,92 poin $(0,63 \%)$ ke level 1.253,23 dan Nasdaq melemah 11,82 poin $(0,44 \%)$ ke level 2/686,15. (http://www.bi.go.id)

Selain pada IHSG, dampak krisis keuangan ekonomi global lainnya dapat juga dirasakan atau dilihat melalui berbagai indikator krisis keuangan global yang mana menurut I Putu Gede 
Ary Suta terdiri dari Nilai Tukar Rupiah/US\$, Tingkat Suku Bunga SBI, Volume Perdagangan, dan Inflasi.

\section{METODOLOGI PENELITIAN Jenis Penelitian}

Jenis penelitian yang digunakan dalam penelitian ini adalah penelitian Deskriptif kuantitatif yaitu penelitian yang berdasarkan data berupa angka-angka yang dijabarkan menjadi suatu analisis secara sistematis. Dalam penelitian ini mencari pengaruh antara variabel independen Nilai Tukar Rupiah/US\$, Tingkat Suku Bunga SBI, Volume Perdagangan, Inflasi dan Indeks Saham Keuangan terhadap variabel dependen Indeks Harga Saham Gabungan (IHSG).

\section{Metode Pengumpulan Data}

Dalam penelitian ini menggunakan data mingguan dari masing-masing variabel yang diteliti selama periode 1 Januari 2011 - 30 juni 2012. Penggunaan data mingguan dilakukan agar data yang diperoleh lebih lengkap, lebih bervariatif dan valid. Penelitian tidak menggunakan data bulanan karena data yang diperoleh akan sangat sedikit sehingga dikhawatirkan tidak valid, sedangkan penelitian tidak menggunakan data harian dikarenakan perubahan yang terjadi setiap hari tidak terlalu signifikan, sehingga tidak terlalu dapat dilihat perubahan harga yang terjadi.

Data seluruh variabel yang akan digunakan dalam penelitian ini adalah data sekunder (secondary data). Menurut Supomo (2002), data sekunder yaitu sumber data penelitian yang diperoleh peneliti secara tidak langsung melalui media perantara (diperoleh dan dicatat oleh pihak lain). Adapun sumber data berasal dari jurnal atau publikasi lain dan situs internet yang memuat informasi yang relevan mengenai hal yang berkaitan dengan penelitian ini.

\section{Deskripsi Variabel Penelitian}

Pada penelitian ini terdapat lima variabel yang akan dianalisis.Variabel tersebut dikelompokkan menjadi dua bagian yaitu variabel dependen adalah Indeks Harga Saham Gabungan (IHSG), dan variabel independen yang digunakan adalah Nilai Tukar Rupiah/US\$, Tingkat Suku Bunga SBI, Volume Perdagangan, dan Inflasi.

\section{Indeks Harga Saham Gabungan (IHSG)}

Menurut Fardiansyah (2002) Indeks Harga Saham Gabungan merupakan suatu indikator perdagangan saham secara umum mencerminkan pergerakan saham di suatu bursa saham. Perhitungan Indeks Harga Saham adalah perbandingan antara harga pasar saham di bursa pada waktu tertentu dengan harga saham pada waktu dikalikan dengan persentase.

\section{Nilai Tukar Rupiah/US\$}

Menurut Adiningsih, dkk (1998), nilai tukar (kurs) rupiah adalah harga rupiah terhadap mata uang Negara lain. Jadi, nilai tukar rupiah/US\$ merupakan nilai dari satu mata rupiah yang ditranslasikan ke dalam mata uang dolar AS. Kurs inilah sebagai salah satu indikator yang mempengaruhi aktivitas di pasar saham maupun pasar uang karena investor cenderung akan berhati-hati untuk melakukan investasi.

\section{Tingkat Suku Bunga SBI}

Sertifikat Bank Indonesia (SBI) adalah surat berharga dalam mata uang rupiah yang diterbitkan oleh Bank Indonesia sebagai pengakuan utang berjangka waktu pendek. Sedangkan suku bunga adalah jumlah bunga yang harus dibayar per unit waktu. Jadi, tingkat suku bunga SBI adalah junlah bunga yang harus dibayar per unit waktu untuk SBI. (Fitriani, 2010)

\section{Volume Perdagangan}

Volume perdagangan adalah banyaknya lembar saham suatu emiten yang diperjualbelikan di pasar modal setiap hari bursa dengan tingkat harga yang disepakati oleh 
pihak penjual dan pembeli saham melalui perantara (broker). Penjualan di pasar modal dikenal dengan istilah lot yang terdiri dari 500 lembar saham dalam setiap satu lot.

\section{Inflasi}

Inflasi adalah suatu keadaan dimana harga barang-barang secara umum mengalami kenaikan dan berlangsung dalam waktu yang lama dan terus-menerus. Harga barang yang ada mengalami kenaikan nilai dari waktu-waktu sebelumnya dan berlaku dimana-mana dan dalam rentang waktu yang cukup lama.

\section{Model dan Teknik Analisis Data}

Proses analisis data dilakukan dengan bantuan Statistics Package for Social Science 16.0 (SPSS 16.0). Software ini dipilih karena kekuatan dan fleksibilitasnya untuk menganalisis data dan untuk mempelajari hubungan pengaruh diantara data yang terkumpul (Norusis, 2000).

SPSS 16.0 (Statistics Package for Social Science 16.0) digunakan untuk menganalisis pengaruh indikator krisis keuangan global terhadap indeks harga saham gabungan (IHSG) dengan menggunakan metode analisis linier berganda (multiple regression analysis model) dengan persamaan kuadrat terkecil (Ordinary Least Square) dengan model dasar sebagai berikut:

Di mana:

$$
\mathrm{Y}=\alpha+\beta 1 \mathrm{X} 1+\beta 2 \mathrm{X} 2+\beta 3 \mathrm{X3}+\beta 4 \mathrm{X} 4
$$

Y = IHSG (Indeks Harga Saham Gabungan)

$\alpha=$ konstanta

X1 = Nilai Tukar Rupiah/US\$

X2 = Tingkat Suku Bunga SBI

$\mathrm{X} 3$ = Volume Perdagangan

$\mathrm{X} 4$ = Inflasi

$\beta 1=$ Koefisien regresi parsial untuk X1

$\beta 2=$ Koefisien regresi parsial untuk X2

$\beta 3=$ Koefisien regresi parsial untuk X3

$\beta 4=$ Koefisien regresi parsial untuk X4

\section{Uji F}

Pengujian ini dilakukan untuk menguji pengaruh secara simultan atau seluruh dari variabel independen secara bersama-sama terhadap variabel dependen.

Langkah-langkah pengujiannya adalah sebagai berikut :

1. Menentukan Hipotesis

H0; $\mu=0$ : Nilai tukar Rupiah/US\$, Tingkat Suku Bunga SBI, Volume Perdagangan, Inflasi dan Indeks Saham Keuangan tidak berpengaruh secara signifikan terhadap Indeks Harga Saham Gabungan (IHSG) perusahaan-perusahaan yang terdaftar di BEI.

2. Menentukan tingkat signifikansi $(\alpha)$ yang digunakan, $\alpha=5 \%$.

3. Membuat keputusan

Jika Fhitung < Ftabel, maka Ho diterima dan H1 ditolak.

Jika Fhitung > Ftabel, maka Ho ditolak dan H1 diterima.

Jika signifikansi $\mathrm{F}>0,05$, maka Ho diterima dan H1 ditolak.

Jika signifikansi $\mathrm{F}<0,05$, maka Ho ditolak dan H1 diterima.

4. Membuat Kesimpulan.

\section{Uji t}

Pengujian ini dilakukan untuk mengetahui pengaruh dari tiap-tiap variabel independen (Nilai Tukar Rupiah US\$ dan Tingkat Suku Bunga SBI) terhadap Indeks Harga Saham Gabungan (IHSG) di BEI untuk periode 1 Januari 2011-30 juni 2012.

Langkah-langkah adalah sebagai berikut: 
1. Menentukan hipotesis

H0 ; $\mu=0$ : Nilai Tukar Rupiah / US\$ tidak berpengaruh secara signifikan terhadap IHSG perusahaan-perusahaan yang terdaftar di BEI.

HO $; \mu \neq 0$ : Nilai Tukar Rupiah / US\$ berpengaruh secara signifikan terhadap IHSG perusahaan-perusahaan yang terdaftar di BEI.

HO ; $\mu=0$ : Tingkat Suku Bunga SBI tidak berpengaruh secara seignifikan terhadap IHSG perusahaan-perusahaan yang terdaftar di BEI.

HO $; \mu \neq 0$ : Tingkat Suku Bunga SBI berpengaruh secara seignifikan terhadap IHSG perusahaan-perusahaan yang terdaftar di BEI.

H0 ; $\mu=0$ : Volume Perdagangan tidak berpengaruh secara signifikan terhadap IHSG perusahaan-perusahaan yang terdaftar di BEI.

HO $; \mu \neq 0$ : Volume Perdagangan berpengaruh secara signifikan terhadap IHSG perusahaan-perusahaan yang terdaftar di BEI.

H0 ; $\mu=0$ : Inflasi tidak berpengaruh secara signifikan terhadap IHSG perusahaanperusahaan yang terdaftar di BEI.

HO $; \mu \neq 0$ : Inflasi berpengaruh secara signifikan terhadap IHSG perusahaan-perusahaan yang terdaftar di BEI.

2. Menentukan tingkat signifikansi ( $\alpha$ ) yang digunakan $\alpha=5 \%$

3. Membuat keputusan

Jika t hitung < t tabel, maka H0 diterima dan H1 ditolak.

Jika t hitung > t tabel, maka H0 ditolak dan $\mathrm{H} 1$ diterima.

Jika signifikansi $\mathrm{t}>0,05$, maka $\mathrm{H} 0$ diterima dan $\mathrm{H} 2,3$ ditolak.

Jika signifikansi $\mathrm{t}<0,05$, maka $\mathrm{H} 0$ ditolak dan $\mathrm{H} 2,3$ diterima.

4. Membuat kesimpulan.

\section{PEMBAHASAN HASIL PENELITIAN}

Dalam pembahasan hasil analisis model atau pengujian hipotesis ini dilakukan dengan cara menggunakan uji asumsi klasik, uji F, uji t, danpengujian hipotesis. Dengan taraf signifkan $\alpha$ $=0.05$ dengan program SPSS 16.0. Data yang akan diolah sebagai berikut:

\begin{tabular}{|c|c|c|c|c|c|}
\hline \multicolumn{6}{|c|}{$\begin{array}{r}\text { Data Mingguan Perkembangan Nilai Tukar Rupiah/US\$, T } \\
\text { Bunga SBI, Volume Perdagangan, Inflasi, dan } \\
\text { IHSG Periode } 1 \text { Januari } 2011 \text { - } 30 \text { Juni } 2012\end{array}$} \\
\hline & X1 & $\mathrm{X} 2$ & X3 & $\mathrm{X} 4$ & Y \\
\hline & Nilai & Suku & Volume & Inflasi & IHSG \\
\hline & $\begin{array}{c}\text { Tukar } \\
\text { /US\$ }\end{array}$ & Bunga SBI & Perdagangan & & \\
\hline 1 & 8942.00 & 0.00125 & 3015.679 .800 & 0.0365 & 3631.45 \\
\hline 2 & 9007.00 & 0.00125 & 3.551 .290 .400 & 0.0365 & 3569.14 \\
\hline 3 & 9018.00 & 0.00125 & 2.059 .844 .400 & 0.0365 & 3379.54 \\
\hline 4 & 8998.00 & 0.00125 & 2.274 .636 .800 & 0.0365 & 3487.61 \\
\hline 5 & 8991.00 & 0.00125 & 1.890 .113 .600 & 0.0365 & 3496.17 \\
\hline 6 & 8878.00 & 0.00129 & 1.733 .171 .100 & 0.0684 & 3391.77 \\
\hline 7 & 8845.00 & 0.00129 & 1.526 .123 .700 & 0.0684 & 3501.50 \\
\hline 8 & 8814.00 & 0.00129 & 2.243 .611 .200 & 0.0684 & 3443.53 \\
\hline 9 & 8768.00 & 0.00129 & 2.199 .271 .800 & 0.0684 & 3542.90 \\
\hline 10 & 8740.00 & 0.00129 & 2.728 .065 .900 & 0.0665 & 3542.23 \\
\hline 11 & 8734.00 & 0.00129 & 2.387 .209 .100 & 0.0665 & 3494.07 \\
\hline 12 & 8678.00 & 0.00129 & 1.790 .452 .900 & 0.0665 & 3607.11 \\
\hline 13 & 8666.00 & 0.00129 & 1.870 .507 .500 & 0.0665 & 3707.49 \\
\hline 14 & 8618.00 & 0.00138 & 2.397 .318 .800 & 0.0616 & 3741.81 \\
\hline 15 & 8617.00 & 0.00138 & 2.195 .946 .600 & 0.0616 & 3730.51 \\
\hline
\end{tabular}




\begin{tabular}{|c|c|c|c|c|}
\hline 8613.00 & 0.00138 & 3.426 .657 .500 & 0.0616 & 3801.08 \\
\hline 8572.00 & 0.00138 & 3.020 .573 .400 & 0.0616 & 3819.62 \\
\hline 8518.00 & 0.00141 & 4.456 .935 .400 & 0.0598 & 3798.55 \\
\hline 8504.00 & 0.00141 & 5.963 .504 .500 & 0.0598 & 3832.02 \\
\hline 8501.00 & 0.00141 & 4.123 .266 .800 & 0.0598 & 3872.95 \\
\hline 8527.00 & 0.00141 & 4.154 .433 .800 & 0.0598 & 3832.38 \\
\hline 8490.00 & 0.00141 & 2.393 .887 .600 & 0.0598 & 3844.02 \\
\hline 8475.00 & 0.00141 & 3.552 .141 .500 & 0.0554 & 3787.6 \\
\hline 8513.00 & 0.00141 & 2.809 .109 .500 & 0.0554 & 3721.38 \\
\hline 8554.00 & 0.00141 & 2.651 .551 .800 & 0.0554 & 3848.56 \\
\hline 8578.00 & 0.00141 & 2.389 .962 .300 & 0.0554 & 3927.10 \\
\hline 8502.00 & 0.00140 & 2.726 .715 .200 & 0.0461 & 4003.6 \\
\hline 8498.00 & 0.00140 & 3.022 .117 .200 & 0.0461 & 4023.20 \\
\hline 8500.00 & 0.00140 & 4.566 .590 .800 & 0.0461 & 4106.8 \\
\hline 8468.00 & 0.00140 & 5.238 .923 .300 & 0.0461 & 4130.80 \\
\hline 8609.00 & 0.00130 & 3.461 .184 .700 & 0.0479 & 3921.64 \\
\hline 8497.00 & 0.00130 & 5.730 .902 .600 & 0.0479 & 3890.53 \\
\hline 8496.00 & 0.00130 & 2.787.381.700 & 0.0479 & 3842.75 \\
\hline 8515.00 & 0.00130 & 2.548 .272 .800 & 0.0479 & 3841.73 \\
\hline 8522.00 & 0.00120 & 2.233 .470 .400 & 0.0461 & 3998.50 \\
\hline 8653.00 & 0.00120 & 2.736 .232 .600 & 0.0461 & 3835.18 \\
\hline 8832.00 & 0.00120 & 2.818 .674 .700 & 0.0461 & 3426.35 \\
\hline 8877.00 & 0.00120 & 3.173 .875 .900 & 0.0461 & 3549.03 \\
\hline 8898.00 & 0.00110 & 2.926.215.100 & 0.0442 & 3425.68 \\
\hline 8883.00 & 0.0 & 4.544 .639 .100 & 0.0442 & 3664.6 \\
\hline 8809.00 & 0.0 & 4.736 .772 .700 & 42 & 3620.66 \\
\hline 8823.00 & 0.0 & 2.171 .689 .300 & 0.0442 & 3829.96 \\
\hline 8885.00 & 0.0 & 3.231 .523 .700 & 0.0442 & 3783.63 \\
\hline 8916.00 & 0.00104 & 2.171 .034 .200 & 0.0415 & 3778.89 \\
\hline 8970.00 & 0.00104 & 2.225 .243 .400 & 0.0415 & 3754.50 \\
\hline 9003.00 & 0.00104 & 2.272 .949 .200 & 0.0415 & 3637.19 \\
\hline 9082.00 & 0.00104 & 2.206 .079 .600 & 415 & 3779.84 \\
\hline 9026.00 & 0.00096 & 2.124 .365 .400 & 0.0379 & 3759.61 \\
\hline 9041.00 & 0.00096 & 3.059 .076 .400 & 0.0379 & 3768.35 \\
\hline 9033.00 & 0.00096 & 1.419 .627 .600 & 0.0379 & 3797.15 \\
\hline 9075.00 & 0.00096 & 816.695 .700 & 0.0379 & 3821.99 \\
\hline 9111.00 & 0.00094 & 3.083 .231 .300 & 0.0365 & 3869.42 \\
\hline 9147.00 & 0.00094 & 3.194 .672 .000 & 0.0365 & 3935.33 \\
\hline 9069.00 & 0.00094 & 3.271 .483 .600 & 0.0365 & 3986.51 \\
\hline 8949.00 & 0.00094 & 1.181 .685 .000 & 0.0365 & 3986.41 \\
\hline 8934.00 & 0.0 & 2.916 .685 .500 & 365 & 4015.95 \\
\hline 8930.00 & & 990.200 & & 3912.3 \\
\hline 8979.00 & & 2.348 .495 .900 & & 3976.5 \\
\hline 9010.00 & 0.0 & 2.534 .946 .000 & 56 & 389 \\
\hline 9066.00 & 0.00 & 2.111 .429 .200 & 0.0356 & 4004.8 \\
\hline 9109.00 & 0.00074 & 756.588 .100 & 0.0397 & 3991.5 \\
\hline 9131.00 & 0.00074 & 1.024 .664 .800 & 0.0397 & 4028.5 \\
\hline 9124.00 & 0.00074 & 2.479 .554 .600 & 0.0397 & 4041.5 \\
\hline 9137.00 & 0.00074 & 2.412 .981 .700 & 0.0397 & 4121.5 \\
\hline 9110.00 & 0.00076 & 3.911 .451 .100 & 0.0450 & 4166.3 \\
\hline 9124.00 & 0.00076 & 3.332 .872 .600 & 0.0450 & 4159.2 \\
\hline 9132.00 & 0.00076 & 3.097 .605 .600 & 0.0450 & 4181.3 \\
\hline 9144.00 & 0.00076 & 3.816 .443 .500 & 0.0450 & 4163.9 \\
\hline 9152.00 & 0.00076 & 2.967 .565 .900 & 0.0450 & 4216.68 \\
\hline
\end{tabular}




$\begin{array}{llllll}70 & 9173.00 & 0.00081 & 2.309 .944 .000 & 0.0445 & 4114.14 \\ 71 & 9209.00 & 0.00081 & 2.899 .207 .200 & 0.0445 & 3980.50 \\ 72 & 9233.00 & 0.00081 & 2.180 .053 .600 & 0.0445 & 3902.51 \\ 73 & 9426.00 & 0.00081 & 1.909 .071 .600 & 0.0445 & 3799.77 \\ 74 & 9392.00 & 0.00083 & 2.444 .382 .200 & 0.0453 & 3825.33 \\ 75 & 9407.00 & 0.00083 & 1.708 .965 .700 & 0.0453 & 3818.11 \\ 76 & 9410.00 & 0.00083 & 1.044 .866 .600 & 0.0453 & 3889.52 \\ 77 & 9436.00 & 0.00083 & 1.451 .629 .600 & 0.0453 & 3955.58\end{array}$

Sumber : http://www.bi.go.id, http://www.yahoofinane.com

setelah data tersebut diolah menggunakan uji asumsi klasik, uji $\mathrm{F}$, uji $\mathrm{t}$, dan pengujian hipotesis maka dapat dijabarkan pembahasannya sebagai berikut:

\section{Pengujian Asumsi Klasik}

Analisis regresi dapat digunakan jika data dari variabel menunjukkan hubungan yang valid atau tidak bias, maka perlu dilakukan pengujian asumsi klasik pada model regresi yang digunakan. Asumsi dasar yang harus dipenuhi antara lain:

\section{Pengujian Normalitas}

Uji normalitas ini dilakukan dengan tujuan untuk menguji apakah data sampel yang diambil telah mengikuti sebaran distribusi normal. Model regresi yang baik adalah distribusi normal atau mendekati normal. Berdasarkan sampel data $(n=77)$, dapat dilihat pada gambar berikut ini:

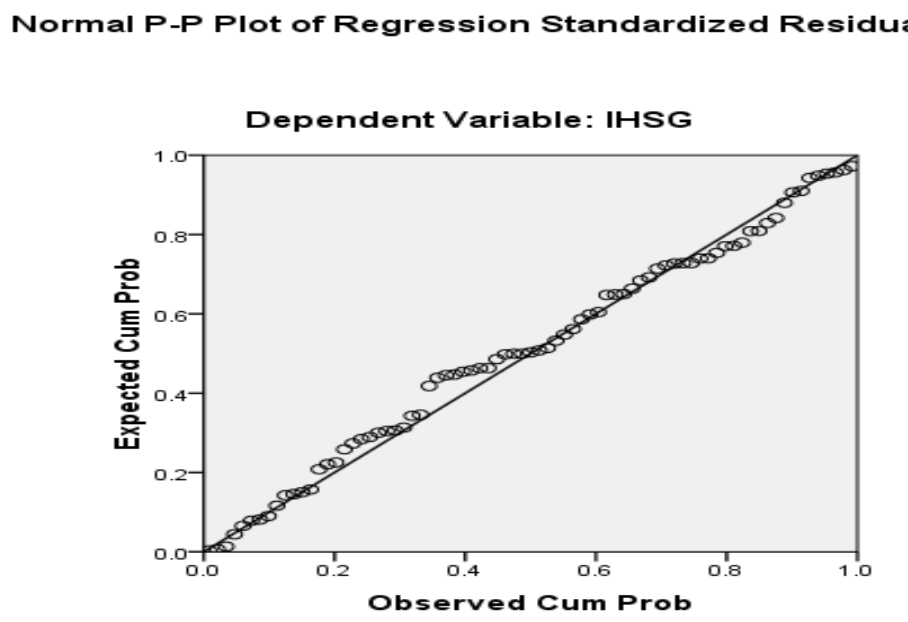

Sumber : Hasil penelitian dengan menggunakan SPSS 16

Berdasarkan gambar di atas terlihat bahwa titik-titik menyebar di sekitar garis diagonal dan mengikuti arah garis diagonal yang berarti bahwa data tersebut normal dan model regresi dapat digunakan.

\section{Pengujian Multikolinearitas}

Multikolinearitas artinya adalah ada hubungan linier yang sempurna diantara beberapa atau semua variabel independen. Uji multikolnearitas bertujuan untuk menguji apakah pada model regresi ditemukan adanya korelasi atas variabel independen. Model regresi yang baik seharusnya bebas multikolinearitas atau tidak terjadi korelasi diantara variabel independen. Untuk menguji asumsi multikolinearitas digunakan VIF (Variance Inflation Factor), dimana bila nilai VIF lebih besar dari 10 berarti terdapat kolinearitas yang sangat tinggi. 
Tabel 1. Hasil Uji Multikolinearitas

\begin{tabular}{|c|c|c|c|c|c|c|c|c|}
\hline \multicolumn{9}{|c|}{ Coefficients $^{\mathbf{a}}$} \\
\hline \multirow[b]{2}{*}{ Model } & & \multicolumn{2}{|c|}{$\begin{array}{c}\text { Unstandardized } \\
\text { Coefficients }\end{array}$} & \multirow{2}{*}{$\begin{array}{c}\begin{array}{c}\text { Standardized } \\
\text { Coefficients }\end{array} \\
\text { Beta }\end{array}$} & \multirow[b]{2}{*}{$\mathrm{t}$} & \multirow[b]{2}{*}{ Sig. } & \multicolumn{2}{|c|}{$\begin{array}{l}\text { Collinearity } \\
\text { Statistics }\end{array}$} \\
\hline & & $\bar{B}$ & Std. Error & & & & Tolerance & VIF \\
\hline \multirow[t]{6}{*}{1} & (Constant) & 5453.246 & 1376.991 & & 3.960 & .000 & & \\
\hline & KURS & -.364 & .124 & -.489 & -2.938 & .004 & .209 & 4.786 \\
\hline & SUKUBUNGASBI & -536834.907 & 156964.398 & -.641 & -3.420 & .001 & .165 & 6.060 \\
\hline & VOLUMEPERDAGANGAN & $-3.143 E-8$ & .000 & -.157 & -1.908 & .060 & .855 & 1.170 \\
\hline & INFLASI & -586.278 & 1926.678 & -.029 & -.304 & .762 & .643 & 1.556 \\
\hline & Lag_Y & .600 & .082 & .603 & 7.347 & .000 & .860 & 1.163 \\
\hline
\end{tabular}

a. Dependent Variable: IHSG

Sumber: Hasil penelitian dengan menggunakan SPSS 16

Berdasarkan pengujian yang telah dilakukan maka diperoleh hasil pengujian yang dapat dilihat pada tabel di atas dan dapat terlihat bahwa nilai VIF kurang dari 10. Berdasarkan hasil tersebut dapat disimpulkan bahwa semua variabel independen bebas dari multikolinearitas.

\section{Pengujian Autokorelasi}

Autokorelasi terjadi apabila gangguan dalam periode tertentu berhubungan dengan nilai gangguan periode sebelumnya. Konsekuensi adanya autokorelasi adalah selang keyakinan menjadi besar serta varians dan kesalahan standar akan ditaksir terlalu rendah. Autokorelasi adalah korelasi antara anggota-anggota serangkaian observasi yang diurutkan menurut waktu (seperti dalam data time series) atau ruang (seperti dalam data cross section).

Pengujian autokorelasi dapat dilakukan dengan uji Durbin Watson. Autokorelasi tidak terjadi apabila DW terletak diantara du dan (4-du) $(\mathrm{du}<\mathrm{DW}<4-\mathrm{du})$. Hasil uji autokorelasi menunjukkan bahwa DW = 1.771 ini berarti bahwa variabel-variabel independen dalam penelitian ini bebas dari autokorelasi.

Tabel 2. Hasil Uji Autokorelasi

Model Summaryb

\begin{tabular}{|l|c|r|r|r|l|}
\hline Model & \multicolumn{1}{|c|}{$\mathbf{R}$} & $\begin{array}{c}\mathbf{R} \\
\text { Square }\end{array}$ & $\begin{array}{c}\text { Adjusted } \mathbf{R} \\
\text { Square }\end{array}$ & $\begin{array}{c}\text { Std. Error of the } \\
\text { Estimate }\end{array}$ & \multicolumn{1}{c|}{ Durbin-Watson } \\
\hline 1 & \multicolumn{1}{|c|}{ S71a } & .595 & .566 & 136.900 & 1.771 \\
\hline
\end{tabular}

a. Predictors: (Constant), Lag_Y, INFLASI, VOLUMEPERDAGANGAN, KURS, SUKUBUNGASBI

b. Dependent Variable: IHSG

Sumber : hasil penelitian dengan menggunakan SPSS 16 


\section{Hasil Uji Analisis Regresi}

Tabel 3. Hasil Uji Analisis Regresi

Coefficients $^{\mathrm{a}}$

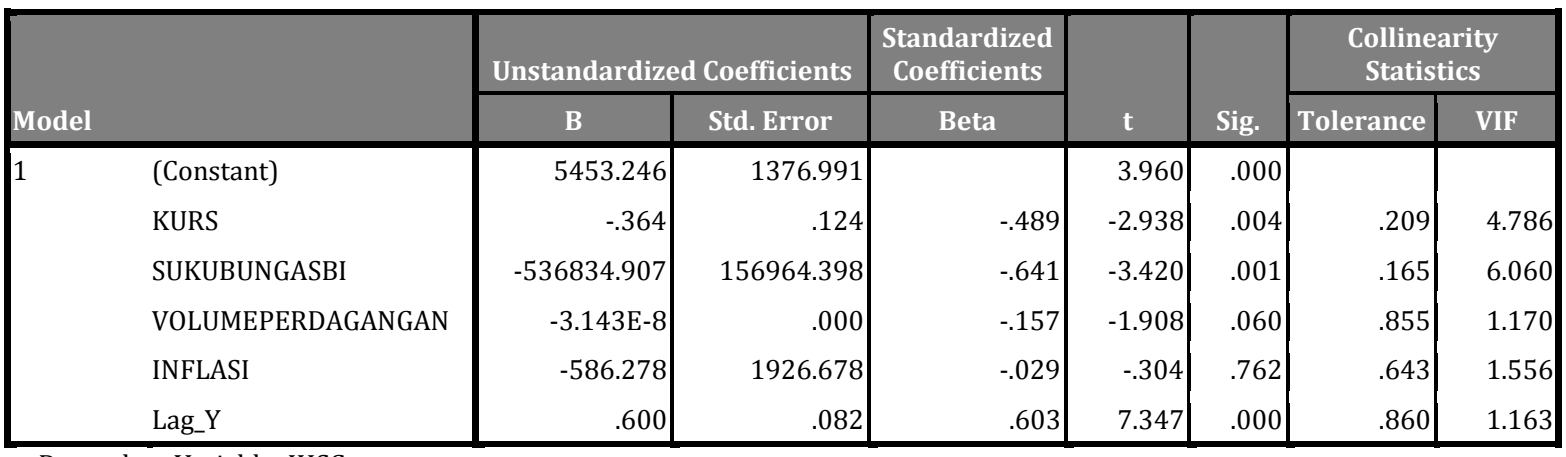

a. Dependent Variable: IHSG

Sumber: Hasil penelitian dengan menggunakan SPSS 16

Berdasarkan formulasi regresi berganda yang digunakan dalam penelitian ini yaitu:

$\mathrm{Y}=\alpha+\beta 1 \mathrm{X} 1+\beta 2 \mathrm{X} 2+\beta 3 \mathrm{X3}+\boldsymbol{\beta} 4 \mathrm{X} 4$

Maka berdasarkan tabel di atas diperoleh model persamaan regresi linier berganda sebagai berikut:

IHSG = 5453.246 - 0.364 X1 - 536834.907 X2 - 3.143 X3 - 586.278 X4

Berdasarkan hasil yang diperoleh peneliti menunjukkan bahwa dari model regresi tersebut diperoleh kostanta sebesar 5453.246 hal ini berarti bahwa tanpa adanya rasio Nilai tukar rupiah/US\$, Tingkat suku bunga SBI, volume perdagangan dan inflasi akan terjadi perubahan IHSG sebesar 5453.246 . Selanjutnya koefisien regresi Nilai tukar rupiah/US\$ sebesar 0.364 dan bertanda ngatif, hal ini berarti satu persen pergerakan Nilai tukar rupiah/US\$ dengan asumsi variabel lainnya tetap maka perubahan IHSG akan mengalami perubahan sebesar $0.364 \%$ dengan arah yang berlawanan. Sedangkan Tingkat Suku Bunga SBI mempunyai koefisien regresi sebesar -536834.907 dan bertanda negatif, hal ini berarti satu persen pergerakan Tingkat Suku Bunga SBI dengan asumsi variabel lainnya tetap maka perubahan IHSG akan mengalami perubahan dengan arah yang berlawanan Koefisien regresi Volume Perdagangan sebesar - 3.143 dan bertanda negatif, berarti setiap perubahan Volume Perdagangan satu persen dengan asumsi variabel lainnya tetap maka perubahan IHSG akan mengalami perubahan sebesar $3.143 \%$ dengan arah yang berlawanan. Koefisien regresi Inflasi sebesar - 586.278 dan bertanda negatif, hal ini berarti satu persen pergerakan Inflasi dengan asumsi variabel lainnya tetap maka perubahan IHSG akan mengalami perubahan dengan arah yang berlawanan.

\section{Koefisien Determinasi (Adjusted R2)}

Koefisien determinasi digunakan untuk melihat berapa persen dari variasi variabel dependen (IHSG) dijelaskan oleh variasi dari variabel independen (Nilai Tukar Rupiah/US\$, Tingkat Suku Bunga SBI, Volume Perdagangan, dan Inflasi)

Tabel 4. Hasil Uji Koefisien Determinasi

\section{Model Summaryb}

\begin{tabular}{|l|c|r|r|r|r|}
\hline Model & $\mathbf{R}$ & $\mathbf{R}$ Square & $\begin{array}{c}\text { Adjusted R } \\
\text { Square }\end{array}$ & Std. Error of the Estimate & Durbin-Watson \\
\hline 1 & $.771^{\mathrm{a}}$ & .595 & .566 & 136.900 & 1.771 \\
\hline
\end{tabular}

a. Predictors: (Constant), Lag_Y, INFLASI, VOLUMEPERDAGANGAN, KURS, SUKUBUNGASBI

b. Dependent Variable: IHSG

Sumber : Hasil penelitian dengan menggunakan SPSS 16 
Nilai koefisien determinasi (Adjusted R2) sebesar 0,566, berarti variasi dari variabel independen dalam menjelaskan variasi variabel dependen IHSG adalah sebesar $56.6 \%$ dan sisanya $43.4 \%$ dijelaskan oleh faktor lain yang tidak diteliti.

Nilai Adjusted R2 untuk IHSG yang besar akan membuat model regresi linier semakin tepat dalam memprediksi IHSG di Bursa Efek Indonesia. Dengan melihat kemampuan model dalam menjelaskan variasi perubahan nilai variabel IHSG, maka model persamaan regresi linier berganda tersebut dapat dinyatakan baik untuk dijadikan sebagai penaksir nilai variabel IHSG yang akan datang.

\section{Koefisien Korelasi Parsial}

Koefisien korelasi parsial digunakan untuk mengukur derajat hubungan antara tiap variabel independen $(\mathrm{X})$ terhadap variabel dependen $(\mathrm{Y})$ secara parsial.

Tabel 5. Hasil Uji Koefisien Korelasi Parsial

Coefficients ${ }^{\mathbf{a}}$

\begin{tabular}{|c|c|c|c|c|c|c|c|c|}
\hline \multirow{2}{*}{\multicolumn{2}{|c|}{ Model }} & \multicolumn{2}{|c|}{ Unstandardized Coefficients } & \multirow{2}{*}{$\begin{array}{c}\begin{array}{c}\text { Standardized } \\
\text { Coefficients }\end{array} \\
\text { Beta } \\
\end{array}$} & \multirow[b]{2}{*}{$\mathrm{t}$} & \multirow[b]{2}{*}{ Sig. } & \multicolumn{2}{|c|}{ Collinearity Statistics } \\
\hline & & B & Std. Error & & & & Tolerance & VIF \\
\hline \multirow[t]{6}{*}{1} & (Constant) & 5453.246 & 1376.991 & & 3.960 & .000 & & \\
\hline & KURS & -.364 & .124 & -489 & -2.938 & .004 & .209 & 4.786 \\
\hline & SUKUBUNGASBI & -536834.907 & 156964.398 & -.641 & -3.420 & .001 & .165 & 6.060 \\
\hline & $\begin{array}{l}\text { VOLUMEPERDAG } \\
\text { ANGAN }\end{array}$ & $-3.143 \mathrm{E}-8$ & .000 & -157 & -1.908 & .060 & 855 & 1.170 \\
\hline & INFLASI & -586.278 & 1926.678 & -.029 & -.304 & .762 & .643 & 1.556 \\
\hline & Lag_Y & .600 & .082 & .603 & 7.347 & .000 & .860 & 1.163 \\
\hline
\end{tabular}

a. Dependent Variable:

IHSG

Sumber : hasil penelitian dengan menggunakan SPSS 16

Koefisien korelasi parsial untuk Nilai Tukar Rupiah/US\$ sebesar 0.209 yang berarti bahwa variabel Nilai Tukar Rupiah/US\$ secara parsial memiliki kekuatan pengaruh terhadap IHSG sebesar 20.9\%. Koefisien korelasi parsial untuk tingkat Suku Bunga SBI sebesar 0.165 yang berarti bahwa variabel Tingkat Suku Bunga SBI secara parsial memiliki kekuatan pengaruh terhadap IHSG sebesar 16.5\%. Koefisien korelasi parsial untuk Volume Perdagangan sebesar 0.855 yang berarti bahwa variabel Volume Perdagangan secara parsial memiliki kekuatan pengaruh terhadap IHSG sebesar 85.5\%. Koefisien korelasi parsial untuk Inflasi sebesar 0.643 yang berarti bahwa variabel Inflasi secara parsial memiliki kekuatan pengaruh terhadap IHSG sebesar $64.3 \%$.

\section{Uji F dan Uji t}

Analisis yang selanjutnya dilakukan adalah analisis terhadap hipotesis dilakukan dengan uji F dan uji t.

1. Pengujian Hipotesis 1

Pengujian Hipotesis 1 dilakukan dengan uji F seperti yang terlihat pada tabel

Tabel 6. Hasil Uji F

ANOVA $^{b}$

\begin{tabular}{|l|r|r|r|r|r|}
\hline Model & Sum of Squares & \multicolumn{1}{|c|}{ df } & Mean Square & F & Sig. \\
\hline $1 \quad$ Regression & 1924194.198 & 5 & 384838.840 & 20.534 & $.000^{\mathrm{a}}$ \\
Residual & 1311914.412 & 70 & 18741.634 & & \\
Total & 3236108.609 & 75 & & & \\
\hline
\end{tabular}

a. Predictors: (Constant), Lag_Y, INFLASI, VOLUMEPERDAGANGAN, KURS, SUKUBUNGASBI

b. Dependent Variable: IHSG 
Pengujian ini bertujuan untuk melihat apakah variabel independen secara bersamasama memiliki pengaruh yang signifikan terhadap variabel dependen. Dengan menggunakan signifikansi 5\% dan degree of freedom (k-1) dan (n-k), dihasilkan nilai $\mathrm{F}$ tabel sebesar 2.335. nilai Fhitung dalam tabel sebesar 20.534 sehingga Fhitung lebih besar dari F tabel (20.534 > 2.335). nilai signifikansinya sebesar 0,000 (sign $<0,05$ ) sehingga Ho ditolak dan Ha diterima. Hal ini berarti bahwa secara bersama-sama variasi variabel-variabel independen indikator krisis keuangan global (Nilai Tukar Rupiah/US\$, Tingkat Suku Bunga SBI, Volume Perdagangan, dan Inflasi) memiliki pengaruh yang signifikan terhadap variabel dependen yaitu IHSG.

2. Uji t Nilai Tukar Rupiah/US\$ dengan IHSG

Pengujian dilakukan dengan uji $\mathrm{t}$ seperti yang terlihat pada tabel. Pengujian ini bertujuan untuk mengetahui pengaruh Nilai Tukar Rupiah/US\$ secara parsial terhadap IHSG di Bursa Efek Indonesia. Dengan menggunakan signifikansi 5\% dan degree of freedom (n-k) = 76 diperoleh $\mathrm{t}$ tabel sebesar 1.992 . dari perhitungan dengan paket program statistik SPSS $16.0 \mathrm{di}$ hasilkan thitung sebesar -2.938 (tanda minus diabaikan) sehingga thitung lebih besar dari ttabel ( $2.938>1.992)$. nilai signifikansinya sebesar 0,004 (sign $>0,05)$ sehingga Ho ditolak dan Ha diterima. Hal ini berarti bahwa variasi variabel Nilai Tukar Rupiah/US\$ secara parsial memiliki pengaruh yang signifikan terhadap variabel dependen yaitu IHSG.

3. Uji t Tingkat Suku Bunga SBI dengan IHSG

Pengujia dilakukan dengan uji t seperti yang terlihat pada tabel. Pengujian ini bertujuan untuk mengetahui pengaruh Tingkat Suku Bunga SBI secara parsial terhadap IHSG di Bursa Efek Indonesia. Dengan menggunakan signifikansi 5\%,dan degree of freedom $(n-k)=76$ diperoleh $t$ tabel sebesar 1.992 . dari perhitungan dengan paket program statistik SPSS 16.0 di hasilkan thitung sebesar - 3.420 (tanda minus diabaikan) sehingga thitung lebih besar dari ttabel (3.420 $>$ 1.992). maka nilai signifikansinya sebesar 0,001 (sign < 0,05) sehingga Ho ditolak dan Ha diterima. Hal ini berarti bahwa variasi variabel Tingkat Suku Bunga SBI secara parsial memiliki pengaruh yang signifikan terhadap variabel dependen yaitu IHSG

4. Uji t Volume Perdagangan dengan IHSG

Pengujian dilakukan dengan uji $\mathrm{t}$ seperti yang terlihat pada tabel. Pengujian ini bertujuan untuk mengetahui pengaruh Volume Perdagangan secara parsial terhadap IHSG di Bursa Efek Indonesia. Dengan menggunakan signifikansi 5\%,dan degree of freedom (n-k) = 76 diperoleh $\mathrm{t}$ tabel sebesar 1.992 . dari perhitungan dengan paket program statistik SPSS $16.0 \mathrm{di}$ hasilkan thitung sebesar -1.908 (tanda minus diabaikan) sehingga thitung lebih besar dari ttabel $(1.908<1.992)$. maka nilai signifikansinya sebesar 0,06 (sign $>0,05$ ) sehingga Ho diterima dan Ha ditolak. Hal ini berarti bahwa variasi variabel Volume Perdagangan secara parsial tidak memiliki pengaruh yang signifikan terhadap variabel dependen yaitu IHSG.

5. Uji t Inflasi dengan IHSG

Pengujian dilakukan dengan uji $\mathrm{t}$ seperti yang terlihat pada tabel. Pengujian ini bertujuan untuk mengetahui pengaruh Inflasi secara parsial terhadap IHSG di Bursa Efek Indonesia. Dengan menggunakan signifikansi 5\%, dan degree of freedom (n-k) $=76$ diperoleh $\mathrm{t}$ tabel sebesar 1.992 . dari perhitungan dengan paket program statistik SPSS 16.0 di hasilkan thitung sebesar -.304 (tanda minus diabaikan) sehingga thitung lebih besar dari ttabel $(304<1.992)$. maka nilai signifikansinya sebesar 0,762 ( $\operatorname{sign}>0,05)$ sehingga Ho diterima dan Ha ditolak. Hal ini berarti bahwa variasi variabel Inflasi secara parsial tidak memiliki pengaruh yang signifikan terhadap variabel dependen yaitu IHSG.

\section{Kesimpulan}

\section{KESIMPULAN DAN SARAN}

Berdasarkan hasil penelitian mengenai Pengaruh Indikator Krisis Keuangan Global terhadap IHSG di Bursa Efek Indonesia periode 1 Januari 2011 - 30 Juni 2012 dapat diambil kesimpulan sebagai berikut:

1. Secara bersama-sama ada pengaruh yang signifikan antara indikator krisis keuangan global (Nilai Tukar Rupiah/US\$, Tingkat Suku Bunga SBI, Volume Perdagangan, dan Inflasi) 
terhadap Indeks Harga Saham Gabungan (IHSG) di Bursa Efek Indonesia (BEI) periode 1 Januari 2011 - 30 Juni 2012, hal ini ditunjukkan dari nilai signifikansi sebesar 0,000.

2. Secara parsial ada pengaruh yang signifikan antara Nilai Tukar Rupiah/US\$ terhadap Indeks Harga Saham Gabungan (IHSG) di Bursa Efek Indonesia (BEI) periode 1 Januari 2011 - 30 Juni 2012, hal ini ditunjukkan dengan nilai signifikansi sebesar 0,004.

3. Secara parsial ada terdapat pengaruh yang signifikan antara Tingkat Suku Bunga SBI terhadap Indeks Harga Saham Gabungan (IHSG) di Bursa Efek Indonesia (BEI) periode 1 Januari 2011 - 30 Juni 2012, hal ini ditunjukkan dengan nilai signifikansi sebesar 0,001.

4. Secara parsial tidak ada pengaruh yang signifikan antara Volume Perdagangan terhadap Indeks Harga Saham Gabungan (IHSG) di Bursa Efek Indonesia (BEI) periode 1 Januari 2011 - 30 Juni 2012, hal ini ditunjukkan dengan nilai signifikansi sebesar 0,06.

5. Secara parsial tidak ada pengaruh yang signifikan antara Inflasi terhadap Indeks Harga Saham Gabungan (IHSG) di Bursa Efek Indonesia (BEI) periode 1 Januari 2011 - 30 Juni 2012, hal ini ditunjukkan dengan nilai signifikansi sebesar 0,762.

6. Nilai koefisien determinasi (Adjusted R2) sebesar 0,566 yang berarti bahwa variasi variabelvariabel independen indikator krisis keuangan global (Nilai Tukar Rupiah/US\$, Tingkat Suku Bunga SBI, Volume Perdagangan, dan Inflasi) menjelaskan variasi variabel dependen IHSG sebesar $56.6 \%$ dan sisanya $43.4 \%$ dijelaskan oleh faktor lain yang tidak diteliti.

\section{Saran dan Keterbatasan}

Berdasarkan kesimpulan di atas maka saran-saran yang dapat diberikan melalui hasil penelitian ini baik kepada investor, perusahaan, maupun untuk pengembangan penelitian yang lebih lanjut adalah sebagai berikut:

1. Investor sebaiknya sangat mencermati berbagai informasi mengenai Nilai Tukar Rupiah/US\$ dan Tingkat Suku Bunga SBI yang dikeluarkan oleh Bank Indonesia (BI) serta jumlah Volume Perdagangan di BEI, dan Inflasi melalui berbagai media cetak maupun elektronik, atau dengan sangat teliti mencermati pergerakan perdagangan di pasar modal karena dengan adanya informasi tersebut dapat dimanfaatkan untuk memprediksi IHSG di BEI yang kemudian dapat digunakan sebagai bahanpertimbangan dalam mengambil keputusan yang tepat sehubungan dengan investasinya.

2. Perusahaan sebaiknya mengkaji atau mengamati laporan keuangan perusahaan terlebih dahulu dengan cermat mengenai semua faktor-faktor yang mempengaruhi besar kecilnya beban perusahaan sebelum melakukan kebijakan seperti ekspor dan impor. Faktor tersebut seperti Nilai Tukar Rupiah/US\$, Tingkat Suku Bunga SBI dan Inflasi, sehingga dalam pelaksanaanya nanti manajemen perusahaan dapat mengambil kebijakan dalam rangka menarik investor di pasar modal.

3. Pemerintah sebaiknya juga memperhatikan faktor makro ekonomi seperti Nilai Tukar Rupiah/US\$ dan Tingkat Suku Bunga SBI melalui kebijakan-kebijakan yang diambil, yang nantinya dapat menarik minat investor baik domestik maupun asing di Bursa Efek Indonesia.

4. Adanya keterbatasan variabel yang digunakan sebagai dasar untuk memprediksi IHSG hanya terbatas Nilai Tukar Rupiah/US\$, Tingkat Suku Bunga SBI, Volume Perdagangan, dan Inflasi, diharapkan pada penelitian yang selanjutnya untuk memperhatikan pengaruh faktor lain yang dapat mempengaruhi pergerakan IHSG.

5. Adanya keterbatasan dalam pengambilan periode penelitian yang hanya 18 bulan, diharapkan untuk pengembangan penelitian selanjutnya dapat memperpanjang periode penelitian agar hasil yang diperoleh dapat lebih merefleksikan pergerakan IHSG di BEI.

\section{DAFTAR PUSTAKA}

Adiningsih, Sri dkk. 1998. Perangkat Analisis dan Tekhnik Analisis Investasi di Pasar Modal Indonesia. Jakarta : P.T Bursa Efek Indonesia.

Fardiansyah, Tedy. 2002. Kiat dan Strategi Menjadi Investor Piawai. Jakarta : Salemba Empat. 
Fitriani, 2010. Pengaruh Indikator Krisis Keuangan Global Terhadap IHSG di BEI. Bengkulu : Universitas Bengkulu.

Norusis, M.J. 2000. Guide to Analysis. New Jersey: Prentice-Hall.Inc.

Satria, Ganendra, 2011. Efek Krisis Yunani. Jurnal Ekonomi.

Supomo. 2002. Statistik Untuk Penelitian. Bandung: Alfabeta.

Suta, I Putu Gede Ary, 2000. Menuju Pasar Modal Modern. Jakarta : Yayasan Sad Satria Bakti.

http://www.bi.go.id

http://www.yahoofinance.com 